\title{
The Development of a Lower- Division, General Education, Course-Integrated Information Literacy Program
}

\section{Gabriela Sonntag and Donna M. Ohr}

\begin{abstract}
Different themes shape the conversation on higher-education reform in the United States today. One of the most important, but least discussed, themes is that of information literacy. Information literacy is important not because it is controversial (everyone agrees that it is important) but, rather, because no traditional academic department has come forward to teach the as-yet-unidentified curriculum that comprises information literacy. At California State University-San Marcos, librarians were successful in having information literacy integrated into the lower-division, general education curriculum. This article defines a model, describes the process that enabled librarians to establish the information literacy program, and offers observations and suggestions for future improvements.
\end{abstract}

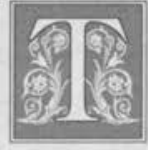

he necessary skills of an information-literate person are those required to access, analyze, and use information to solve a problem or make a decision. ${ }^{1}$ Confusion surrounds the definition of information literacy, with some placing heavy emphasis on computer skills. Although computer literacy is vital, it is not enough. Information literacy involves making people aware of information so that they become educated "information consumers." Essentially, information-literate people have learned how to learn. Businesses are turning to universities and demanding graduates who can identify problems and solve them creatively us- ing the same skills that librarians have identified as information-literacy skills. ${ }^{2}$

Unfortunately, higher education is not meeting the needs of our society adequately. Works such as A Nation at Risk and Higher Education and the American Resurgence call for educational reform so that students become active and responsible participants in the teaching/learning experience. ${ }^{3,4}$ Institutions of higher education are being asked to provide students with critical thinking and problemsolving skills that will enable them to compete in today's changing workplace. These demands are well documented in Training America: Strategies for the Nation, which recommends that instruction needs

Gabriela Sonntag is Coordinator of the Information Literacy Program, Library and Information Services, at California State University-San Marcos; e-mail: gsg@mailhost1.csusm.edu. Donna M. Ohr is an Information Literacy Consultant in La Jolla, California. 
to change in order to emulate real-world interdisciplinarity. ${ }^{5}$ Higher education should be preparing students for today's world, a world of information, rapid change, and incredible complexity. Patrick Hill writes: "In the traditional classroom, however, almost every course or program has been carefully narrowed to a departmental or disciplinary focus, frequently an extraordinary abstraction from what the real-life problem is." 6

Numerous works also cite the importance of information literacy for society as a whole. ${ }^{7}$ Such works recognize that citizens must be able to sift through the overwhelming and sometimes contradictory information needed to make decisions for a healthy democracy. To be informed, this citizenry must have information skills, especially those that involve evaluating information critically, looking for bias, authority, and supporting facts.

It is disconcerting that little attention is paid to the role of libraries in highereducation reform and, more specifically, in the education of students as "information consumers." In libraries throughout the United States, librarians understand that it is not enough to give a tour of the library or to stand in front of a class for fifty minutes and lecture on how to conduct the research needed for a specific assignment. It is no longer sufficient to teach students how to use the library as traditional bibliographic instruction did in the past. As a result of the proliferation of media and computerized resources that have increased the amount of information available to students, librarians must teach students not only how to access this information but also how to evaluate it critically. Further, students must be able to identify that they have an information need, understand what information resources exist to meet that need, and understand how to wield that information. ${ }^{8}$ In short, students must be taught information literacy. Two major contributions pertinent to the role of libraries in education address this dilemma. The Fi- nal Report of the American Library Association Presidential Committee on Information Literacy details the importance of educating an information-literate society and emphasizes the need for active, resourcebased learning as the primary means of achieving this goal. ${ }^{9}$ In this type of learning environment, students and faculty become active participants in challenging each other and searching for new answers.

Support for the role of libraries in educational reform is found in Patricia S. Breivik and E. Gordon Gee's groundbreaking work entitled Information Literacy: Revolution in the Library. ${ }^{10}$ This work emphasizes the need for partnerships between the university and the community, the library and the classroom, and the library and the university administration. These partnerships would allow for full use of the library as a vital resource for informed decision-making and as a learning laboratory. Educational reforms that incorporate resource-based education and active learning are needed and, if used, can meet the demands of American businesses and help form the partnerships that Breivik and Gee describe. Active, resource-based learning greatly impacts the role of the library on the university campus. As a primary resource and as the gateway to the world of information, the library is critical to the teaching/learning experience. The case for active learning and other alternatives to the traditional lecture is well documented. ${ }^{11}$ Library-based information literacy activities are excellent opportunities for active learning involving experiencing and observing. Integrating these activities into the classroom can help reinforce course content and can address various learning styles. ${ }^{12}$

Active learning activities transform the traditional model of the library as a "warehouse of knowledge" to one of a "learning laboratory." In this model, students are motivated by their own interest not just in acquiring information for 
the sake of memorization, but also in actively seeking answers to questions and solutions to problems being discussed in their courses. These answers or solutions become class assignments or research papers using the information resources available through (not just in) the library. Instructing students in using this laboratory and its tools becomes the educational mission of the library and the primary responsibility of instruction librarians. Active learning becomes the vehicle by which information literacy instruction is delivered.

This vision of the library as a learning laboratory forms the backbone of the Information Literacy Program (ILP) at California State University-San Marcos and can serve as a model for other institutions looking to incorporate this needed reform.

\section{The Setting}

California State University-San Marcos (CSUSM) is the twentieth campus of the California State University system and, at the time of its founding in 1989, the newest public university to be built in California in more than twenty-five years. The university has three colleges-Arts and Science, Business Administration, and Education-and offers master's degrees in mathematical sciences, psychology, sociological practice, literature and writing studies, business administration, and education, as well as nine teachercredentialing programs. Beginning in fall 1995, CSUSM expanded to a four-year program admitting first-year students, bringing enrollment to approximately 3,000 students.

Within this setting, the vision of the library as a learning laboratory is on its way to becoming reality. In addition to librarians as teachers of information skills, the CSUSM library's vision encompasses a reform of the general education curriculum to include an information literacy requirement. The following describes how this model of library-based information literacy was integrated into the General Education Program (GEP) at CSUSM. $^{13}$

\section{Initial Support}

Early plans for developing the ILP were presented initially at the Librarian's Policy Input Meeting in early 1992. After some revisions, the library faculty and the dean of library services endorsed the program. This "homebase" support added strength to library efforts on campus.

The need to persuade administrators and teaching faculty about the importance of information literacy and library use skills is commonly cited as one of the

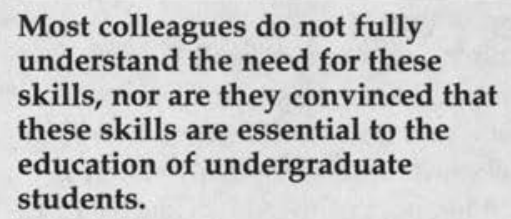

major obstacles that librarians face. Most colleagues do not fully understand the need for these skills, nor are they convinced that these skills are essential to the education of undergraduate students. As one writer stated, "the real challenge of the 1990's is for instructional librarians to develop the necessary political skills to convince faculty colleagues and administrators that there is a coherent set of intellectual skills in information-seeking that can be taught, evaluated, and dovetailed with the larger goals of the institution."14

Recognizing this, the library took the first major step toward realizing its vision of truly integrating information literacy instruction. In February 1993, the instruction librarian and the provost attended the second Bibliographic Instruction Conference at Redlands University. Evan Farber and faculty from Earlham College presented their program and made a strong case for integrating library-use assignments into numerous courses. Im- 
pressed by the conference, the provost became an active supporter of the ILP.

That same month, when a task force convened to develop the GEP at CSUSM, the instruction librarian on the task force advanced it. The committee acknowledged the need to include information literacy in the criteria for developing courses and to include it as an aspect of the philosophy statement. In fact, it is one of the areas in which university-level competency should be attained. ${ }^{15}$ Because its report had to be adopted by the Academic Senate, the task force conducted numerous forums for faculty, staff, administration, and students that provided an opportunity to educate the campus community on the importance of the library's vision.

Other support for the ILP came from the report of the Western Association of Schools and Colleges Accreditation Team, which visited the campus in March 1993, and the report of the CSU Council of Library Directors entitled Transforming CSU Libraries for the 21st Century. Both reports reinforced library efforts to establish an information literacy requirement into the GEP. ${ }^{16,17}$

\section{General Education Program}

Within the guidelines established by California State University, and as delineated by Title $\mathrm{V}$ of the Education Code of the State of California, the lower-division GEP is divided into five areas: Area A (basic skills), Area B (math and science), Area C (humanities and arts), Area D (social sciences) and Area E (lifelong understanding). The entire program does not exceed forty-eight units of credit. Area A encompasses a total of nine units of written communication, oral communication, and critical thinking. Area B is divided into two options. In the first, science majors would have a designated life science course and a designated physical sciences course tailored to their needs, but also open to nonscience majors. In the second option, a six-unit core course for nonsci- ence majors would cover the life and physical sciences at a level appropriate for them. A math course, three units, also is required and several math courses appropriate to the majors are offered. Areas C and D offer a six-unit core course supplemented by one three-unit elective in the area. Three units must be taken in Area E. Upper-division GE includes nine units in Areas B, C, and D. This program was approved by the Academic Senate in April 1993.

By April 1994, when the College of Arts and Sciences sponsored a weekend retreat for faculty and administrators to discuss the implementation of lower-division GE, the library had already developed the goals and objectives of the ILP using ACRL's Model Statement of Objectives for Academic Bibliographic Instruction. ${ }^{18}$ Separate goals, objectives, and competencies were written for each area. They function as ILP's "course criteria" and form the basis for discussions with faculty. ${ }^{19}$

During the faculty retreat, the provost announced the availability of faculty development funds earmarked for lowerdivision GE. The library seized this opportunity and proposed a full-day workshop for faculty entitled "Integrating Information Literacy into the Classroom Using Alternative Teaching Techniques." The workshop, conducted by Debra Gilchrist (Director, Pierce College Libraries) and Cathy Yetter (Assistant Professor, School of Education, Pacific Lutheran University), included a general discussion of information literacy and its philosophical basis, effective library assignments, teaching techniques that incorporate active learning, and finally how to integrate information literacy into an active learning environment.

The Academic Senate approved the task force report establishing the GEP and subsequently formed a General Education Committee to establish policies and procedures regarding the program, and to approve courses developed by the faculty in accordance with the GE course 
criteria. The Academic Senate bylaws guarantee the library a permanent presence on this committee. In the first year, the committee chair was a librarian, who received one course release per semester as compensation for her duties.

\section{The Model}

The structure of the GEP allowed ILP to focus goals and competencies. In the core courses (Areas B, C, and D), librarians teach students how researchers in the various disciplines work. They introduce students to basic information resources in those disciplines and help them develop the skills necessary to use them. For example, the first goal of the ACRL Model Statement of Objectives, "How information is identified and defined by experts," becomes the goal in Area B, "How information is defined by the scientist."

The criteria for lower-division GE courses require that the faculty demonstrate how information literacy and use of the library will be represented in their courses. To ensure this, core courses in the sciences, humanities, and social sciences have a librarian as part of the instructional team. In the Area A courses, students learn how to use a library (the traditional goal of bibliographic instruction), and the courses include aspects of evaluation of sources, critical thinking, and critical listening. The course meeting the requirements for Area $\mathrm{E}$ focuses on understanding the electronic library and targets student use of technology while introducing students to issues on the Information Age. This "freshman experience course" will also use software entitled Getting Published, which will help students learn about academic research by simulating the scholarly publishing cycle. ${ }^{20}$

Targeting all GE courses will reach a wide spectrum of students, but will leave transfer students at a general disadvantage. The local community colleges that act as feeders to CSUSM advise students on the importance of taking library-use courses already in existence before trans- ferring. In addition, the ILP has plans to develop a three-unit upper-division Area $E$ class aimed at enhancing the information competencies of transfer students.

\section{Observations}

Looking back, the authors are aware of several factors that worked in favor of the development and implementation of this model for information literacy instruction. Having garnered the support of the administration from the very beginning may be seen as going against common wisdom, which looks to faculty support before implementing a new program. But having the provost convinced that this program was not only important, but also possible, proved to be one of the most valuable assets.

\section{But having the provost convinced that this program was not only important, but also possible, proved to be one of the most valuable assets.}

Without the support of the provost, the library would not have been able to get the two new positions requested to support the ILP in fall 1995.

Another advantage was the high visibility of librarians on campus. By working in the Academic Senate on the Executive Committee, as senators, and with representation on every Academic Senate committee, as well as universitywide committees, librarians play an active and visible role in making the program a reality. ${ }^{21}$ Librarians also forged "pedagogical allies" with faculty by attending workshops and institutes related to pedagogy that were offered for GE faculty. Librarian involvement in these workshops provided more personal contact with faculty, especially in the group activities that allowed faculty the opportunity to view how librarians grapple with similar pedagogical considerations when designing a class or a lecture. 
This kind of permeation of librarians throughout the university, from the administrative and policy level to the collegial level, has been one of the key factors in the model's success. Such widespread involvement also fostered the acceptance of library faculty as colleagues by discipline-based faculty.

The ILP has also received very strong support from the dean of library services not only in "advancing the cause" with the administration, but also in providing for release time, advocating the need for two additional library faculty to devote more than one-half their time to the ILP, finding opportunities to request extraordinary funds, and facilitating understanding within the library itself of the changing role of the instruction librarians.

Hindsight allows the authors to recognize that some aspects of the ILP were not ideal. One drawback is CSUSM's new campus status. The faculty workload includes not just teaching, but also developing new courses, new programs, new majors, and the committee work necessary for creating a new campus. This unusual workload may explain why (despite its being a criterion for course development) the need to incorporate information literacy was not always well received. However, librarians developed the diplomacy necessary to know when not to broach the subject, leaving it for a more appropriate moment. Several faculty were not shy about their information illiteracy, which afforded librarians the opportunity to discuss the program comfortably and facilitate understanding of ILP goals.

Another drawback involves the faculty workshop, which could have been more successful had it been available to faculty after they had begun to develop their courses. This timing would have better prepared faculty to discuss enhancing content through active learning information literacy assignments. Yet another drawback was the lack of overlap in participation among the various groups: task force, workshop, GE faculty, and/or the
General Education Committee. These groups rarely included the same people. However, this can be seen from both perspectives. The lack of overlap in participation did not allow for in-depth understanding of the program on the part of the faculty, but it did enable a larger number of faculty to be introduced to the concept.

\section{Future Implementation}

As the library becomes a learning laboratory, the role of the library faculty is changing. ${ }^{22}$ Despite some heated debate regarding who should be responsible for teaching information literacy, a strong case has been made for librarians as the ones most suited to teach information management skills. ${ }^{23}$ In addition to teaching, librarians at CSUSM will be involved in evaluating student learning and curriculum development.

A successful program is never "finished." The program as a whole and its component modules must be constantly evaluated, reworked, updated, and tailored to user needs. Librarians must be aware of these needs, and be proactive and prepared with suggestions for assignments and resources. Adequate staffing for developing, implementing, evaluating, and redesigning this program is a major concern. As librarians are seen more frequently in the classroom, the administration becomes more aware of who they are and what they do. This visibility enhances the library's ability to request funding for positions and materials. Course release time is also paid to the library for its participation in the Area E course.

Because of the unique aspects of this program and the planned growth of CSUSM, the ILP will continue to develop faculty workshops in close collaboration with the Faculty Center on campus. These will focus on aspects such as the effective integration of information literacy in the classroom and active learning assignments that emphasize problem-solving 
and inquiry. Instructional tools that support coursework also will be developed so that different methods of student learning can be addressed. Audiovisual programs will complement learning in the classroom and hypertext programs, such as Getting Published, will supplement instruction. As programs are designed and developed for individual courses, the library expects to be working even more closely with members of computing and telecommunications, forming a team with the instruction librarians.

The CSUSM library model expands on efforts at other colleges and universities.
California State University is experiencing a debate on remedial education. Nationally, institutions are looking to reform their GEPs. At CSUSM, librarians are spearheading this reform. They have acknowledged that most students are underprepared when it comes to researching and thinking critically, analyzing information, and using it. The GEP and the ILP, because they are mandated and an integral part of all GE courses, will put CSUSM in a position to prepare its students for a solid university career and provide them a better opportunity to succeed in this informationbased world.

\section{Notes}

1. American Library Association, Presidential Committee on Information Literacy: Final Report (Chicago: ALA, 1989).

2. Jan Kennedy Olsen and Bill Coons, "Cornell University's Information Literacy Program," in Coping with Information Illiteracy: Bibliographic Instruction for the Information Age; Papers Presented at the Seventeenth National LOEX Library Instruction Conference Held in Ann Arbor, Michigan, 4 and 5 May 1989, eds. Glenn E. Mensching and Teresa B. Mensching (Ann Arbor, Mich.: Pierian Pr., 1989).

3. National Commission on Excellence in Education, A Nation at Risk: The Imperative for Educational Reform. A Report to the Nation and the Secretary of Education (Washington, D.C.: NCEE, 1983).

4. Frank Newman, Higher Education and the American Resurgence (Princeton, N.J.: Princeton Univ. Pr., 1985).

5. Anthony P. Carnevale and Janet W. Johnston, Training America: Strategies for the Nation (Alexandria, Va.: American Society for Training and Development, 1989).

6. Patrick Hill, "Who Will Lead the Reform of Higher Education? Librarians, Of Course," Washington Center News 5, no. 2 (1991): 5.

7. Carol C. Kuhlthau, Information Skills for an Information Society: A Review of Research (Syracuse, N.Y.: ERIC Clearinghouse on Information Resources, 1987).

8. Paula T. Kaufman, "Information Incompetence," Library Journal 117 (Nov. 15, 1992): 37-39.

9. ALA, Presidential Committee on Information Literacy.

10. Patricia S. Breivik and E. Gordon Gee, Information Literacy: Revolution in the Library (New York: Macmillan, 1989).

11. Charles C. Bonwell and James A. Eison, Active Learning: Creative Excitement in the Classroom, ASHE-ERIC Higher Education Report, no. 1 (Washington, D.C.: George Washington University, School of Education and Human Development, 1991).

12. Sonia Bodi, "Teaching Effectiveness and Bibliographic Instruction: The Relevance of Learning Styles," College \& Research Libraries 50, no. 2 (Mar. 1990): 113-17.

13. At the seventh National Conference of ACRL, the authors presented a poster session explaining the CSUSM General Education Program and the Information Literacy Program. The response to this poster session was overwhelming, with more than 200 requests for information. To meet this demand, a homepage was created for the program, which can be accessed at <URL:http://coyote.csusm.edu/cwis/cwis/library/ilp/page_one.html>. This homepage provides further links that help illustrate the CSUSM model. Numerous libraries from around the country continue to call or send e-mail or letters inquiring about the program as their institutions consider reforming their general education requirements.

14. Craig Gibson, "Accountability for BI Programs in Academic Libraries: Key Issues for the 1990's," in Assessment and Accountability in Reference Work, eds. S. G. Blandy et al. (New York: Haworth Pr., 1992), 103.

15. See the ILP Web site for GEP Philosophy Statement. 
16. Western Association of Schools and Colleges, Report of the Visiting Team for Initial Accreditation (San Marcos, Calif.: California State University, 1993), 51.

17. CSU Council of Library Directors, Transforming CSU Libraries for the 21st Century: A Strategic Plan of the CSU Council of Library Directors (San Marcos, Calif.: California State University, 1994).

18. ACRL Bibliographic Instruction Section, Model Statement of Objectives for Academic Bibliographic Instruction (Chicago: ALA, 1988).

19. The ILP Web page explains further the various aspects of the General Education Program and requirements for the specific courses.

20. The Getting Published software was developed with the assistance of a University Grant for Technological Innovation. More information about this program is available at the ILP Web page or from the authors.

21. A librarian was chair of the Senate in 1993-94, and there has been a librarian on the Executive Committee every year so far. A librarian is also one of the two at-large representatives to the Statewide Academic Senate.

22. New challenges to librarians are well outlined by Hannelore Rader in "Information Literacy: A Revolution in the Library," RQ 30, no. 1 (fall 1991): 25-29.

23. Various authors address the expanding role of the librarian in the educational mission of the university. Most notable are Patricia S. Breivik, "Information Literacy: Revolution in Education," in Coping with Information Illiteracy; Betsy Baker and Mary Ellen Litzinger, eds., The Evolving Educational Mission of the Library (Chicago: ALA, 1992); Hill, "Who Will Lead the Reform?"; and Maureen Pastine and Bill Katz, Integrating Library Use Skills into the General Education Curriculum (New York: Haworth Pr., 1989).

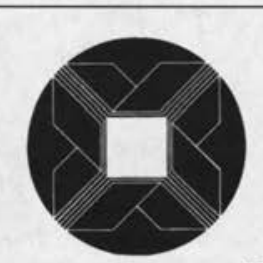

\section{NEW FROM THE ASSOCIATION OF RESEARCH LIBRARIES Order via the ARL Online Catalog: http://arl.cni.org/pubscat/}

Directory of Electronic Journals, Newsletters and

Academic Discussion Lists, 6th Edition. June 1996

Copyright and the NII: Resources for the Library and

Education Community. May 1996

The Economics of Information in the Networked Environment.

May 1996

Scholarship, Research Libraries, and Global Publishing.

April 1996

Digitizing Technologies for Preservation.

March 1996

The Age Demographics of Academic Librarians: A Profession Apart. February 1996

Publications Dept, 21 Dupont Circle, Washington, DC 20036/202-296-2296 